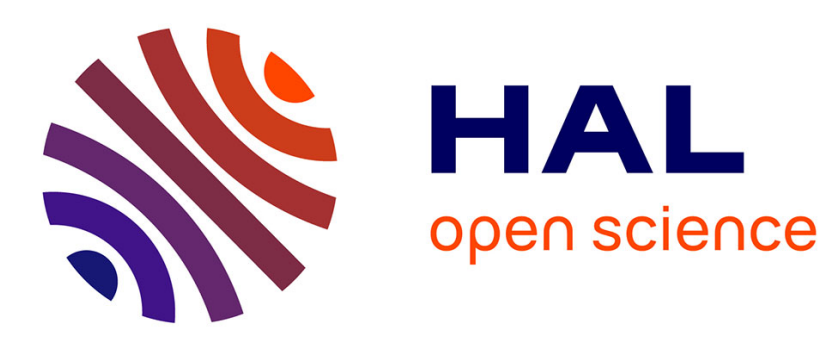

\title{
The importance of responsible-innovation and the necessity of 'Innovation-care'
}

\author{
Xavier Pavie
}

\section{To cite this version:}

Xavier Pavie. The importance of responsible-innovation and the necessity of 'Innovation-care'. 2013. hal-00690404v2

\section{HAL Id: hal-00690404 \\ https://essec.hal.science/hal-00690404v2}

Preprint submitted on 24 Sep 2013

HAL is a multi-disciplinary open access archive for the deposit and dissemination of scientific research documents, whether they are published or not. The documents may come from teaching and research institutions in France or abroad, or from public or private research centers.
L'archive ouverte pluridisciplinaire HAL, est destinée au dépôt et à la diffusion de documents scientifiques de niveau recherche, publiés ou non, émanant des établissements d'enseignement et de recherche français ou étrangers, des laboratoires publics ou privés. 


\section{The Importance of Responsible- innovation and the Necessity of 'Innovation-care'}

\section{Research Center \\ ESSEC Working Paper 1203}

2012

Updated September 2013

\section{Xavier Pavie}

Publication forthcoming in Philosophy of Management

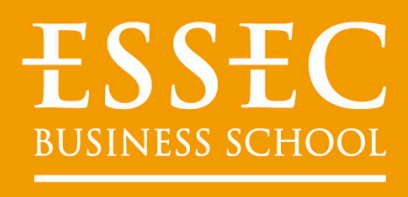




\title{
THE IMPORTANCE OF RESPONSIBLE-INNOVATION
}

\author{
AND THE NECESSITY \\ OF 'INNOVATION-CARE'
}

Xavier Pavie, $\mathrm{PhD}^{1}$

${ }^{1}$ Research Associate at IREPH (Université Paris Ouest) - Director of ESSEC-ISIS (Institute Strategy Innovation Service). ESSEC Business School, Av Bernard-Hirsch, BP 50105 Cergy. 95021 Cergy Pontoise Cedex - France.pavie@essec.edu 


\section{$\underline{\text { SUMMARY }}$}

This study deals with responsibility as part of innovation. By nature, innovation gives birth to development for the organization and can only be at the core of any strategy within an ever-increasingly global economic context. However it also raises new questions stemming mostly from the impossibility to forecast the success of the innovations. More precisely, the questions raised by innovation also concern its consequences on society as a whole. Today, the innovator should understand his responsibility, the consequence of each innovation.

Moreover, common acceptance of the word 'responsibility' raises some questions about its use and bow it should be understood. What does 'responsibility' mean? Who is responsible and for what? Through the notion of 'care', we aim at providing an evolution of responsible-innovation. The concept of 'innovation-care' is centered on people and more precisely focuses on taking care of them. The purpose of innovation-care is indeed to innovate and keep up with the level of productivity necessary to any organization while taking into account the essential interdependence between the status of the innovator and that of the citizen.

\section{KEY WORDS.}

Innovation, responsibility, care, innovator, individuals, performance, interdependence, ethics. 


\section{INTRODUCTION : INNOVATION, RESPONSIBILITY AND CARE}

When François Rabelais wrote in the 16th century in Pantagruel his famous sentence "Science without consciousness is nothing but the death of the soul" , was he aware that five centuries later it would still be a topical question? Was it an early attempt to fight the modernity his century would enter with Descartes, his almost contemporary? Whatever it was, if we look at the environment we live in today, we cannot deny that he had a vision. Electronics has invaded our everyday life with the 'digitalization of the world' which is becoming a major issue at stake and can be seen, for instance, in the increasing presence of nanotechnologies. It seems that it is only the beginning, considering the progress to come both in the exploitation of the human body and in its avatars, as automatons play an ever-increasingly important role in various parts of our everyday lives. In the meantime, these new ways to communicate have been related to the development of democratic movements in the countries where freedom of expression is limited. In addition, medical headway supported by technology is naturally praised by its beneficiaries.

We could thus start studying the notion of innovation by introducing the Greek term deinon, famous for its multiple meanings, making it difficult to translate accurately. It means both the ideas of the terrible and of the admirable which unite to imply the power of opposites. Sophocles in Antigone illustrated this idea by the example of the man who has "resources, whose ingenuous skill is above all expectations, he moves sometimes towards evil, sometimes towards good"3. However, the ones who innovate are the individuals, they are the ones who can choose in which way to direct innovation: "sometimes towards evil, sometimes towards good", consciously or not. The responsibility to choose between 'to make or not to make' is finally borne by innovators. Nevertheless, the very word responsible is unclear in its meaning and leaves space for misunderstanding in the notion of "responsible innovation".

The unprecedented rise of technology and of its power occurs in a context of accelerating globalization. The innovator is more particularly concerned by his responsibility for the world that does not yet exist but which will be impacted on and shaped from the innovations launched on the market. It is by its novelties, its launches of products and services that the face of the world is outlined. Thus, it is appropriate to talk about responsible-innovation, which thereby underlines the role of responsibility in innovation, to take care of humanity.

That is the reason why we first suggest focusing on the fundamental question of responsibility by underlining the fact that, as Marc Neuberg says, the responsibility of innovation lies in the consideration of situation within a value system shared by all the actors impacted by that process ${ }^{4}$. We shall then describe what 'responsible-innovation' may be, pointing out, at that stage, criticisms concerning misunderstanding of the concept or, more exactly, the shades of meaning of responsibility. As a result, we shall opt for a proposition which, in our judgment, casts a new light on the issue that every innovation has to deal with: the individual. That is why we shall use the notion of care. Having defined this term, we shall explore the meaning of 'innovation-care', its principles, and its uses for the society, for the company and for the innovator. As a conclusion we shall be careful not to lose sight of the very essence of innovation according to Schumpeter: economic performance 5 .

\footnotetext{
2 Rabelais, 1854, p.107

${ }^{3}$ Sophocles, 1955, p.86

${ }^{4}$ Neuberg, 1997

${ }^{5}$ Schumpeter, 1939
} 


\section{PART I: THE NEED OF RESPONSIBILITY FOR THE INNOVATOR}

\section{About the Importance of Responsibility}

By nature, innovation cannot be predicted. Despite the many surveys and market studies conducted prior to launching a new product or service, there is no denying that the outcomes of an innovation can only be known once the product is on the market. When Schumpeter described innovation he particularly underlined this aspect: innovation occurs when the product is launched on the market and attracts enough customers to become significantly profitable ${ }^{6}$.

In the case of Facebook, for instance, the ensuing phenomenal societal consequences of this innovation and the degree of responsibility which has been placed on Mark Zuckerberg's shoulders could never have been predicted before the launch. Indeed, Zuckerberg had never planned that Facebook would eventually register its millionth user (and beyond), thereby placing its founder at the top of a gigantic, ever-growing database. All markets as we know them, have their own specificities and consist of a dynamic set of forces constantly changing and interacting with one another - which means that one can never foresee the ultimate consequences of a new product, service or process until after it faces these forces directly.

This situation of uncertainty is the basis on which a lot of studies are made, aiming to reduce the risks of failure. Paradoxically enough, few people wonder about the consequences of this uncertainty, should it lead to a success or not. Yet it is this very uncertain feature which gives birth to the issues at stake within the concept of responsible-innovation, whose essence is to question the consequences of an innovation.

If we look at the air conditioning innovation, a system based on modifying, controlling and regulating climate conditions for reasons of comfort, we can see clearly that the detrimental effects on the environment could never have been predicted. At the time the system was being developed, which started in the late 1930s with Cadillac's initial trial and continued into the late 1950s, scientific knowledge concerning environmental issues was only in its infancy. Moreover, the United States of the 1950s was essentially focused on progress, innovation and comfort rather than the environment. In this way, the installation of air conditioning systems in motor vehicles became a standard from the end of the 1980s onwards and it is nowadays rare for a newly-built car not to have such a function. However, it is important to note that a vehicle with an air conditioning system releases 15\% more CO2 emission than a vehicle without ${ }^{7}$. Statistics from the Energy Information Administration ${ }^{8}$ predict a $39 \%$ increase in emissions by 2030 , mainly caused by cars. This presents very high risks, which are now known, for the environment and society as a whole? These could never have been predicted sixty years ago, considering the insufficient amount of scientific knowledge at the time.

A similar level of uncertainty applies to innovations within the finance sector. Banks and their financial product innovations were held responsible for the economic downturn, following the recent financial crisis. New topics on 'responsible-innovation' are nowadays often found in the media. This comforting and seemingly moral notion is aimed at reassuring the customers on both the moral values of their supplier and the security of the financial product they are offered.

The understanding of the notion 'responsible-innovation' leaves room for a large number of interpretations. Its evolution is deeply rooted in the notion of social responsibility for the firm. Nonetheless the stake of that social responsibility has in fact little to do with innovation. Since it

\footnotetext{
${ }^{6}$ (Schumpeter, 1939)

7 (Gagnepain, 2006)

8 Sources: History: Energy Information Administration (EIA), International Energy Annual 2006 (JuneDecember 2008), web site www.eia.doe.gov/iea. Projections: EIA, World Energy Projections Plus (2009).

${ }^{9}$ www.arehn.asso.fr/dossiers/clim/climatisation.html
} 
concerns mostly short and middle-term issues, social responsibility cannot highlight the specificities of innovation, not even mention its uncertain outcome ${ }^{10}$.

\subsection{Responsibility: A New Dimension in the Innovation World}

We can determine the meaning of 'responsible-innovation' by firstly focusing on the notion of progress, that is, the permanent desire of humans to 'progress' towards a goal that is profitable for the individual. It is only when we think in those terms that Descartes' sentence - which made the 16th century enter an age of modernity and progress, in other words the race for innovation - can reach the full extent of its meaning: we human beings "have to render ourselves the lords and possessors of nature" 11 . This opinion, which was justified in the 16th century - all the more so that it was concerned with protecting men's health ${ }^{12}$ - has rarely been questioned. The race to progress and innovation, which thrived on economic development, has kept going faster ${ }^{13}$.

Among the French philosophers of the $18^{\text {th }}$ century, we can quote Condorcet who suggested using the future outcomes of medical sciences to create an endless human life ${ }^{14}$. Benjamin Franklin, whose fantasy was to be able to interrupt and start life again, showed similar interests ${ }^{15}$. Charles Darwin underlined that chances were that humankind as we know it today, had not reached the end of its evolution and was rather at its very beginning ${ }^{16}$.

The point of these ideas is the human being's need for 'progress', should it be in terms of knowledge or sciences. The notion of progress has long been studied in close link with medical headway or the conservation, creation and extension of human life. Although religion has always limited some possibilities of progress in the past and present day (concerning life reproduction for instance), the scientists had neither the knowledge nor the ability to realize such ambitious projects at the time of Descartes or Condorcet. However, over the last ten or twenty years the pace of medical progress has clearly increased with the discovery of genetics, the DNA structures and the first attempts to clone animals. The issue no longer lies in the ability of science to realize a project; it is now in responsibility's concern of the choice between doing or not doing ${ }^{17}$.

Innovation, the daughter of progress, has continued to develop ways to meet the goal to improve or to ease all aspects of the life of individuals, their conservation as well as their well-being. It has been helped in this particular area by the development and the progress of technology, which has enabled people to develop many products and services whose existence was pure fantasy less than a century ago. Today, for instance, 'transhumanism' has become a goal whose public stake is the improvement of the human condition through technology. These forms of technological support aim, for instance, at fighting the gradual weakening of the human body and condition brought about by old-age, and at increasing our intellectual, psychological and body capacities ${ }^{18}$. Even if those in favor of transhumanism acknowledge the possible risks stemming from the rise of such

\footnotetext{
${ }^{10}$ Porter and Kramer, 2011

${ }^{11}$ Descartes, 1953, p.168

12 Emmanuel Faye shows that to get all the possible "commodities" on earth is not the prevailing aim; it is in fact the "preservation of health" with the intent to make mankind "wiser". It implies to have knowledge of the "reasons" for our sicknesses and of "all remedies provided by nature". Cf. E. Faye, Heidegger, l'introduction du nazisme dans la philosophie : autour des séminaires inédits de 1933-1935, Albin Michel, «Idées », 2005.

${ }^{13}$ The appearance of the first criticisms at the beginning of the 60's can be noted, for one Rachel Carlson in Silent Spring, Mariner Book Edition, 2002

${ }^{14}$ Condorcet, 1822

${ }^{15}$ Franklin, 1956

${ }^{16}$ Darwin, 2003

17 Among a very large range of examples, the latest birth of the first "life-saving baby" can be noted. The parents of a little girl suffering from a genetic disease have decided to have another child that could save her. The parents of this "life-saving baby" benefited from a double pre-implantation diagnostic. First the embryos that carried the sickness were ruled out; then, among the remaining ones, the one that matched the best the gene pool of the sibling was selected and finally it was implanted in the mother's womb. If such a technical achievement should be celebrated, one can wonder about the development of such a technique which opens the way for eugenics.

${ }^{18}$ www.transhumanism.org
} 
new technologies, they are deeply convinced that the benefits outweigh the risks, especially in terms of fighting poverty, sickness, disabilities, lack of food and dictatorships. The improvement of the quality of life of the individuals being the ultimate goal, those theorists only see in the concept of 'nature' something unclear and hampering progress ${ }^{19}$.

This casts a new light on the risks and threats for human values. There is today a new emphasis on sustainable and responsible development. Thanks to the progress of science and technology, we can understand complexity. These developments make way for a lot of actions which imply ethical, social and citizenship-related concerns. Yet the success and uses originating from these developments result in new risks whose consequences cannot be foreseen. Responsibility should thus now be understood as the subject of common agreement, because as François Ost explained: "nowadays we are responsible, or at least responsible together, for common actions whose development and effects remain unknown; the circle of closeness which made me feel duty-bound only towards the close future and my neighbor is broken, just like the link of simultaneity which made me responsible for the present effects, or the effects directly inferring from the actions I made today" 20 .

\subsubsection{Exogenous Conditions}

Exogenous conditions are closely linked to the economic pressures in which firms operate, and even more so to a strong and globalized form of competitiveness, which emphasizes the importance of the innovation process, and makes it more difficult to apply the dimension of responsibility. Firms must keep up with the competitive environment, aiming at a strong and perfect productivity, or they are to be killed by this very same competitiveness. It seems that a kind of economic Darwinism is working, which entails a fight for economic survival and results in the elimination of the weakest.

The results of a study conducted between September, 2009 and January, 2010 where 1,541 CEOs, Presidents and Directors of public and private organizations and firms of different sizes in 60 different countries over 33 sectors $^{21}$ were interviewed, illustrates the need for firms to be robust to survive very clearly. In this survey, some firms are described as being 'super-productive', especially in terms of innovation, according to their economic results in the short and long term. Results showed that the over-productive organizations managed to improve their operating margin both in the long and short term. They were also able to better overcome the global financial crisis than the others, thanks to their robustness, acquired and constantly reinforced in this highly-competitive environment.

Two specific features of these 'over-productive' firms can be identified. Firstly, these organizations accept responsibility for taking decisions in conditions of uncertainty. Indeed, $16 \%$ more of them implement reiterated processes of strategic planning, instead of formal annual planning process. Secondly, they are able to make up their minds faster than the others. More exactly, 54\% are said to be in favor of quick decisions. Yet these two factors work against responsible innovation, as they do not foster reflection about the possible negative consequences of an innovation: making up one's mind in a state of uncertainty leads to risks. Being able to make up one's mind quickly is as risky as having no control on the factors and the consequences.

\subsubsection{Endogenous Conditions}

Endogenous conditions are closely linked to exogenous ones and also influence the responsibility. They deal with two major issues. Firstly, the fact that the average timespan a CEO stays in office keeps decreasing. Over the last ten years, the average lifetime of a CEO decreased by $25 \% 0^{22}$. When asked about it, CEOs claimed to barely have enough time to imagine a strategy when they come into office. Their concern and obsession must be the publication of the results to come. But this

\footnotetext{
${ }^{19}$ Bostrom et al, 2008

${ }^{20}$ Ost, 1995 , p. 267

21 IBM. 2010, Institute for Business V alue, Capitalizing on Complexity, (IBM Corporation).

${ }^{22}$ Favaro et al, 2010
} 
publication cannot be made separately from the announcement of a strategy, of future innovations and projects, even if they are at the very beginning of their development. From this moment on, there is no space for doubt; no question can be raised, even if it is the very essence of innovation to be in a state of uncertainty. In order to remain in their position, these CEOs have to maintain the PR buzz surrounding their announcement and guarantee the success of the innovation. This results in an explosion of media hype with their competitors. Because this system is difficult to maintain over the long term, CEOs are always granted a shorter lifetime in their job.

A second factor whose responsibility is often borne by the CEO needs to be taken into consideration. CEOs have a particularly close link with innovations, and are often considered as their 'fathers'. In a study carried with 1,130 directors, from all areas and continents, they claimed that the responsibility of innovation was borne by them. $50 \%$ of respondents claimed "I am the innovator" or that it belonged "to all the employees" 23 (which implies, in the last case, the directors being at the apex of the hierarchy). If an innovation fails, is the director responsible for it? If he is, what made him responsible for it and to which extent? Is there an obsession to innovate as soon as pride and ambition are stressed?24

\section{Axes of Responsible-Innovation}

We will now analyze three elements suggested by Bensaude-Vincent ${ }^{25}$ to help determine what issues responsible-innovation deals with, in the form of the following three axes.

The first one emphasizes the fact that in the world today, every firm is - rightly - obsessed with listening to their customers, so that it will be able to meet their needs. The principle of responsibleinnovation questions this, wondering if a new need should always be met. In other words, the discovery of an unsatisfied need does not necessarily justify the launch of an innovation. Should innovation strategies do everything they can to meet a new need? For example, should we launch an internet service which automatically writes students' coursework, because the latter do not want to do $i t^{26}$ ?

The second aspect of responsible-innovation is simply that innovators cannot calculate or predict all the consequences of the products they launch. All the more so that in the meantime there is a race for innovation which entails quick decisions (sometimes even adopted in a hurry). As a result of the challenging business environment and of the increasing number of firms, all the competitors can think about is launching their most recent product on the market, whatever the consequences might be. The famous Ford Pinto, which sadly earned the nickname "The Barbecue that sits four", is a telling example. The vehicle was made lighter by strategically placing the fuel tank closer to the rear: an innovation in itself, having reduced the production process by nearly half the time. The 301 standard comprised of a leakproofness test of the shell, to protect passengers from explosion. Despite failing the 301 standard test (which at the time was only recommended by the National Highway Traffic Safety Administration and not compulsory), the car was launched on the market. Ford was forced to recall all vehicles from the market by 1978, following complaints. The procedure cost the firm $\$ 20$ Million $^{2728}$.

The third and last level of responsible-innovation is that innovation can result in new risks, whose consequences can impact everyday life and ways of life. This topic is of great importance and yet it is often sidelined. An innovation may have no bad consequences on the "eco-system" it is meant to reach but it can have an impact on an unforeseen target and result in some damage. In the case of launching a new more powerful, faster, and louder sounding airplane, the consequences should not only be assessed on the members of the staff and on the customers. The damages stretch to all the beings in contact with it, should they be human or animals. It is the whole ecosystem around the

23 IBM, 2008, Global CEO Study, (IBM Corporation).

${ }^{24}$ Raymond, 2003

25 Bernadette Bensaude-Vincent, introduction au Colloque innovation responsable du 29 avril 2009, Collège de France.

26 Libération du 7 mars 2009, «Faismesdevoirs.com ferme déjà ses pages ».

27 Shaw \& Berry, 1995

${ }^{28}$ Raymond, 2003 
airports which is harmed, as the Grenelle de l'environnement underlined, and decisions will have to be made in the light of the full range of stakeholders. ${ }^{29}$

\section{Progressing from Responsibility to Care}

\subsection{Common Misunderstandings About the Meaning of 'Responsibility'}

The previous elements underline what responsible-innovation can be, in the form of an innovation initially stemming from a client's need, which the firm, institution or organization decides to meet by developing a specific solution, which in turn enables it to grow with profit while being aware of the possible damages on the economy, society and environment in the short, middle and long-term.

Yet 'responsible-innovation' seems to face too many limits as we will discover, which result in an impossible understanding of the notion, and thus in an impossible implementation of it within the structures of the innovative organization.

In order to make the following analyses of responsibility clearer in this particular context, we will begin by clarifying innovation as a theoretical concept. As Schumpeter (1939) suggested, innovation can take many forms, from being a whole new product or a set of changes made to an existing one, to being a new process, the discovery of a new market, a new source of supply or even any change made within an organization. In a similar way, innovation has been defined as a process which creates value and provides a degree of novelty to the organization, suppliers and customers. It involves developing new procedures, solutions, products and services and new ways of marketing ${ }^{30}$.

The first point is about responsibility as part of innovation. Who is responsible of innovation, in terms of implementation? Who 'has to account for its decisions' as the Latin etymology respondere suggests? This question is very important when it comes to analyze a phenomenon such as the development of autonomous working groups. The first consequence of these working-groups is the dilution of responsibility ${ }^{31}$. We know that the dilution of responsibility in general results in a careless assessment of consequences. We obviously feel less concerned by the impact of innovation when there is no clear definition of who in the management chain makes the decisions ${ }^{32}$. Responsibility can only be approached when one is directly accountable for an entire item - even a small one - not only a part of it.

Secondly, responsible-innovation is often shown as hampering innovation. Just as much as 'innovation' is characterized by development, growth, headway and progress, being 'responsible' is associated with brakes, slow motion and patience. Because one may have 'to account for' what one did, the rhythm of the innovation automatically has to be slower. The fear of bearing responsibilities for one's acts is an incentive for wait-and-see policy, should it be from a lack of courage or a will to avoid problems.

Another point concerns the common acceptance of the term 'responsible'. For what and for whom would an innovation be responsible? What is the object of responsibility? Is it the preservation of the generations to come? Or of the current generation? Is responsibility about groups, communities or individuals? We can see the importance of these questions if we refer back to the uses of the term 'responsibility' dating from the $18^{\text {th }}$ century, and bear in mind its link at that time with the idea of solidarity. The evolution of the concept at that time was closely linked to the restructuration of schemes of civil responsibility, including the prevention of risks. It is at that period that the notions of responsibility and fault broke apart, just like insurance, indemnification, etc. In fact, it became a tool that allowed people to assess risks, rather than a regulative principle of behavior. Yet, it had a

${ }^{29} \mathrm{http}: / /$ www.legrenelle-environnement.fr/Convention-avec-les-acteurs-du.html. For that matter, the measures intending to reduce noise pollution for the sake of the local residents' well-being increase the planes' consumption of kerosene in the same time.

${ }_{30}$ Covin and Slevin, 1991; Lumpkin and Dess, 1996; Knox, 2002

${ }^{31}$ Baber, 1983

32 Baber, 1983 
paradoxical consequence: the "relieving responsibility of each act"33. From this moment on, according to Laurence Engel: "Responsibility without fault tends to lead to the weakening of responsibility" 34 .She argues that this applies both before and after the act of making a decision. In the case of the former, it translates into an imposition of liability, without taking the behavior of the individuals being held liable into consideration. It therefore acts as an anesthetic and numbs the action, thereby producing a feeling which is completely opposite to that of responsibility. Once the decision has been made, responsibility without fault does not identify the mistakes which may have been committed and therefore essentially 'destroys' the feeling of responsibility as the person who pays compensation for the fault may openly declare that it is not their fault (Engel, 1997).

Paul Ricœur argues that the term respondere is often misunderstood and suggests that we replace it by imputare, the imputation. According to him, the notion of responsibility should be stretched towards imputation so as to increase the value of the relation with each-other. Ricœur's argument also raises questions for responsible-innovation. He says that "the new meaning responsibility has been given in our technological period needs an orientation openly directed towards a far future, which goes beyond the time of consequences we can predict" (Ricoeur, 1995). Yet imputation seems too close to juridical questions, because imputation seeks the 'fault' and characterizes it for the subject, which is useful but in no way sufficient. Indeed, the challenge facing us at this present time is not so much of a legal nature, but rather destined to engage a new understanding of the issues at stake for innovators, whose main goal is to foster the growth of their organizations. In other words, innovators are currently not as concerned with the consequences of their innovation on society as they are with the lack of satisfactory performance results from their innovation. It is thus necessary to find a new concept, a new dimension, a new understanding which would provide us with an answer to this lack of substance. This concept should enable us to understand more completely what is at stake in the relation of the individual, with himself as with someone else. This does not mean that responsibility should adopt a sense of moral fault or other legal characteristic. It is rather a question of placing the act of caring for others as the ultimate aim for innovation.

In other words the point is to think about innovation as a means whose result would be better for the individuals, because it would take care of them. It would highlight an issue which responsibleinnovation does not tackle enough. Taking care of the individuals should naturally lead society towards better outcomes. This is the reason why we suggest using the British and American notion of care. This one, coupled with the notion of innovation, should enable us to reach a new paradigm, including a new conception of the innovator's role, and help us to set up a more accurate approach of what responsible-innovation should be. This paradigm could be placed under the aegis of Plato who said, in 'The Republic' that the City should be established not only for "a single class of privileged citizens, to whom the possession of happiness would be granted, but so that happiness would belong to the higher number of people we can reach, to the whole State" 35 . Thus, reformulating the Athenian, innovate-care is to innovate for the City while seeking not only the exceptional happiness of a single group, but happiness for as many individuals as possible, that is to say the whole of civil society.

\footnotetext{
${ }^{33}$ Ewald, 1996, p.86

${ }^{34}$ Engel 1997, p.86

35 Platon, 1950, p.980
} 


\section{PART II: THE PURPOSE OF INNOVATION-CARE}

\section{Emergence of Care Beyond the Social Sciences}

Care can be understood as solicitude, taking care of someone or kindness ${ }^{36}$. It is the universal expression of human concerns about the world we live in ${ }^{37}$ and is used by many academics and practitioners in different disciplines. And yet it seems important today to question its position within the managerial circle, especially concerning innovation ${ }^{38}$. Given that the concept of care is closely linked to the relationships between individuals, Joan Tronto, one of the most influential writers on the concept of care, underlines the need to question the concept by institutions, cities and States ${ }^{39}$. He emphasizes that from the point of view of the ethics of care, morals are drawn from everyday life experiences, and the problems faced by real people in their routine life ${ }^{40}$. This is the reason why I argue here that firms should be added to this list.

From the start, Joan Tronto and Berenice Fischer define care as "a typically human activity which includes everything we do, so as to maintain, preserve or fix our 'world', aiming at living in it in the best conditions. This world includes our bodies, our individualities and our environment, because we try to mix it in a complex pattern which is the underlying basis of life" 41 . Innovation associated with care does not completely match this definition, because not every technological, scientific, economical innovation aims at 'fixing' the world or our bodies - even if it might have been the aim of progress. Yet innovation should not run the risk of destroying the world, the environment or individuals. As soon as innovation is integrated into everyday life and crosses into the individual's privacy, it needs to develop a sense of care towards the preservation and development of the ecosystem at the heart of which it operates.

This definition reveals also that care is focused on the present and innovation-care on the future. While care aims to take care of the one who currently needs it, innovation-care aims to meet the future needs of individuals without forgetting to care for them. We should note that the argument of this paper puts together ethics, responsible-innovation and care. In doing so, it echoes the views of Bernard Williams, who has stated that the basis of ethics is to be found in Socrates' question: "How should we live?" 42 . This can be expressed in even more a Socratic manner: by which knowledge can we reach the 'good way of life'? Innovation-care is based on these two pillars: first 'taking care of oneself' - epimeleia heautou - and secondly ethics, which is here linked with Socrates.

We must distinguish innovation-care from the notion of care-innovation. The latter focuses more particularly on innovations in relation to the practice of care and the behaviour of carers (school attendants, baby-sitters and so on). Innovation-care is thinking about individuals when assessing the consequences of innovation, and as such, it can be any innovation (should it be technological, scientific or economic). Among these different areas, the key question is how care for others arises within the process of innovation.

The purpose of innovation-care is essentially centered on placing innovation back into a social context. This is crucial since, as stated earlier, innovation as currently conceived is often trapped within managerial circles and freed only to listen to the consumer and detect commercial prospects. Innovation-care considers the society within which the product is being launched, so as to enable the latter to focus on individuals. We can wonder if innovation within this framework is a return to Descartes' thought, for his will to see men "as lords and possessors of nature" was, as we said, strongly correlated with progress for the preservation of the individual and of health ${ }^{43}$.

\footnotetext{
${ }^{36}$ Laugier et al, 2008

${ }^{37}$ Gilligan, 2008

38 Tronto, 2003

39 Paperman, 2008

${ }^{40}$ Laugier et al, 2008

${ }^{41}$ Fisher et al, 1993, p.37

42 Williams 1990

${ }^{43}$ Descartes, 1953
} 
We can now see that, in the same way that responsible-innovation must be kept separate from corporate social responsibility, innovation-care goes a step beyond the latter and builds on sustainable development issues to ultimately place the sense of caring for others as the final strategic goal for innovation.

\section{Fields of Expression of Care}

For Joan Tronto, care must be conceived in terms of a collective consciousness, because all of us benefit from it. It means that it is the attention we pay to the caring for somebody else which enables the existence of a collective care. Yet it raises the question of ability: what do we know about the techniques of caring for someone? What do we know about what is done for us? The movements and the attitudes which the others give and have for us weave together the preservation, coherence and even the aesthetics of our lives ${ }^{44}$. How could the manager know about caring for someone? These questions are just as acute when it comes to innovation: what do we want for our lives? How should we answer it? What are our intentions and are they consistent?

Innovation-care raises once more these questions about the forms an innovation can adopt, in order to formulate them according to personal inner needs. It questions the decision to launch an innovation on the market when its ultimate purpose is opposed to, or clearly contrasting with, universal principles. The point here is to reflect beyond the economic aspects of innovation, such as the market share that this or that innovation will provide. This reflection does not lie so much within the business variables as it does within the individual. The point is thus to innovate for the others in the same manner we would innovate for ourselves, as Kant would have said.

Joan Tronto highlights that in care there is a dyad which articulates two kinds of individuals, the care-giver on the one-hand, who gives the care, and the one who benefits from it on the other with a balance of power in favor of the first of these ${ }^{45}$. Analogously, this superiority of the giver is also to be found in the notion of innovation-care. Just like the innovator, the firm which innovates has power over its customers - who benefit from the innovation and whom the firm knows because it has studied their needs and habits. This power, which the innovator may be tempted to abuse, is a main aspect of innovation-care which gives rise to this concern: to which extent can I exploit the weakness of someone who needs me? Let us take an extreme - but nonetheless real - example: the case of a weapons dealer, which innovates by creating a more effective weapon. What or who does this firm really decide to take into account when innovating?

\subsection{The Individual's Spheres}

The innovative environment raises the issue of the private life versus the professional life, especially for the innovator. Western firms - as well as governments - have tended to promote the need for a strict boundary between what deals with one's career and one's personal life as a private citizen; the famous concept of work/life balance. The point is to enable individuals to have a personal life protected from their work. In the meantime, this policy results in a potential unawareness or voluntary denial of the consequences of each 'life' on the other. The fact that we want the manager to be a citizen who does not think about their work implies that we want them to stick to their work when at the office; we want them to give up their citizenship and everything it implies when they enter the firm building. The most important consequence this dichotomy implies, among others, is that the manager's main focus should be the company rather than civil society. Indeed, to which extent does a manager wonder "I have before me an innovation which could be successful and thus good for the firm. Its success could even enable me to get a promotion, should I give up because it has negative impacts?" We can notice the discrepancy between power, concern and care here, which can result in several possible conflicts for the manager. How will the manager answer this question? Will they base their judgment on their personal values? Their morals? Values and morals, however, are very difficult to establish on a worldwide basis, if not impossible ${ }^{46}$. A morally worthy decision in Asia might not be considered so in Africa, and in addition morals themselves

\footnotetext{
${ }^{44}$ Fisher et al, 1990

45 Tronto, 2003

${ }^{46}$ Schwartz, 2005
} 
vary from one person to the next and can also be influenced by demographic factors such as gender (Laugier et al, 2008). The dichotomy manager/citizen should be explored once more. Is the separation between manager and citizen to be supported, or should we on the contrary articulate these two roles in order to strike a happy medium?

Responsibility in innovation has to be defined by listening to all who are affected by it, that is to say it implies a responsibility which reflects on the individuals the innovation can reach - should they be customers, citizens, potential customers, etc. Not only must the innovator understand that they are also a citizen, but also that their professional sphere aims to take care of their private life. This is what Empedocles tried to teach us, reformulated by Jean-François Balaudé "There cannot be a human community fair and living in harmony if its members do not think and behave like members of the superior community of living beings." ${ }^{47}$. In other words, innovators must always remain citizens, citizens working for the civil society and the community to which they belong.

The interaction between the private and professional sphere is the interdependence between manager and citizen, between innovators and innovation-benefiters as a whole. This follows our reasoning above, as the private life and values of a person cannot be separated from the part that they play in the public sphere. The issue then lies in the extent to which these spheres merge and the degrees to which a manager will allow his personal value and morals as a citizen influence his decisions as a manager impacting the public sphere.

Interdependence can be found in today's globalization of products and services, between people, should they be directors or employees, and in some cases even within the inner-self of a single individual: the manager and the citizen. Interdependence is everywhere, whether we like it or not. The goal of care is to accept this interdependence while taking care of oneself and of others. Being aware of interdependence is understanding that a malicious or irresponsible action will always turn against oneself, just as we benefit from the care given to someone else ${ }^{48}$. This is why care theories underline the importance of showing that each one of us depends on the services of others for the meeting of our basic needs ${ }^{49}$. In the care perspective, oneself and others are not represented as distinct items: the relationship is the central object from which the moral subject perceives needs and meets this perception.

A wide range of practices and perspectives deal with seizing the relations between you and the others ${ }^{50}$.

From medicine to driving on a road, from education to information, from management to collaboration within a project-group there is interdependence. In order to understand this concept, one has to leave their self-centered sphere, which is precisely what most firms and directors find the hardest, especially within the innovation framework. The offer of innovation-care is, on the one hand, to show that innovation is no lonely stake, and on the other hand, that failure does not mean weakness but is simply due to human characteristics.

${ }^{47}$ Balaudé, 2010, p.117

48 Gilligan, 2008

${ }^{49}$ Laugier et al, 2008

${ }^{50}$ Laugier et al, 2008 


\section{PART III: INNOVATION-CARE AND SELF-CONTROL}

Innovation-care underlines the fact that we cannot pretend that we are self-sufficient - a reality which must essentially be accepted by the innovator as by anyone else. It is an awareness of the interdependence that exists between individuals, firms, countries among others, and of the possible exchanges taking place at the boundary between private and public spheres. Once an innovator becomes aware of living within a process where they receive care and benefits from others, they can understand the notion of care, as it applies to their practice. In other words, they can then understand what it is to personally aim at being 'caring' through their innovations.

Once these mixed-processes are understood, innovation can no longer pretend to be sure to bring happiness to people: in given contexts it can naturally do this, but tool often it may have negative consequences in relation to care as we have described this above. Joan Tronto distinguishes between 'good' and 'bad' care by referring to the significant example of those European colonists in preceding centuries, who thought that they were not taking advantage of the people they wished to rule ${ }^{51}$. The same criticism may be raised about innovation. For instance, by producing yet another iPod which contains more functions and options than previous ones, the innovator may firmly believe that he or she is clearly benefitting the consumer. However, considering the long-term impacts of using rare resources in the production process of such a product, the innovator may not take into account that he or she is contributing to the eventual decrease in the quality of life of the consumer and global citizens.

In the case of the study mentioned in the earlier part of the paper, which revealed that so-called 'super-productive' firms were better able to survive in highly-competitive environments, it seems that these are essentially concerned with listening to their customers, constantly focusing their research on them to ensure every single need is discovered and subsequently satisfied through a product or service. Putting the customer at the core of one's strategy thus becomes almost an obsession. In fact, $95 \%$ of these firms stated that "tying closer bonds with the customer" was their priority ${ }^{52}$. Yet there is more to innovation-care than this. While the innovator may believe that something is 'good' for him or herself or for the customer, it may not necessarily be the case for the rest of society. Implementing innovation-care however requires listening to the opinion of others, all of whom may well become impacted by the potential innovation. However those 'other' opinions will not necessarily match the opinions of potential customers. Nevertheless, and going by the principles of innovation-care, the process needs to be fair and requires taking into account the opinions of all the actors who could suffer from the consequences of a future innovation. This also ties in the concept of interdependency, which can occur between customers and non-customers and may therefore become a means of transferring consequences to individuals who were initially not in direct contact with the innovation.

The importance of this issue is evident when we consider incremental innovations, since these are often initially seen as the most valuable kinds from the customer's perspective. However, the most topical issues concerning the possible consequences of an innovation are raised when dealing with breakthrough innovations. Incremental innovations are by nature more predictable, because there is at least a small part of them on the market. On the other hand, a breakthrough innovation requires more attention because its consequences are fully unknown.

In order to define innovation-care, we need to adopt a holistic approach, whereby one not only acts for the sake of oneself, the firm or one's nation, but also for the sake of society as a whole. A cigarette-producer must think about non-smokers; a producer of domestic cleaning detergents should concern themselves with the treatment of water after its products will have been in contact with it, and about the children playing with this water or anyone else who may come in contact with it; a car-seller should consider the pedestrians and cyclists with whom cars share the road.

In the end, the evolution of the paradigm innovation-care is just a resurgence of the act of thinking according to Kantian principles, in particular his different formulations of the categorical

\footnotetext{
51 Tronto, 2003

${ }^{2}$ IBM. 2010, Institute for Business V alue, Capitalizing on Complexity, (IBM Corporation).
} 
imperative. One of these, ("act that your principle of action might safely be made a law for the whole world" ${ }^{33}$ ) highlights interdependence, the obligation to look for the global consequences and the fact that others, in the meantime, can have the same concerns as oneself, instead of a personal and individual look. In other words, this principle could be the basis of innovation-care: always act while caring, that is to say bringing into line our actions with a universal look on what we are just about to do.

Another formulation is: "Act in such a way that you treat humanity, whether in your own person or in the person of any other, always at the same time as an end and never merely as a means to an end" 54 . In this case, innovation-care is particularly emphasized, as humanity is to be preserved and that is a goal in itself. This Kantian principle, just as the last one, attempts to make individuals a necessary prerequisite for any action.

\subsection{From the Innovator to the Innovator-Carer?}

The maxims of Kant and more generally the principle of innovation-care require a completely new human behavior, concerning others and oneself. When Hans Jonas introduced the "responsibility principle" he wondered if humanity had a right to exist ${ }^{55}$. If the answer to this question is yes, then it is essential that human beings evolve towards a new behavior, one that is caring for the world; a new stance that individuals in their large acceptance must take. Faced with the rise of technology and its power, with a worldwide globalization, human beings have to bear their responsibilities for the world and within the world.

These issues require a questioning of the innovator's profile. An innovator should adopt a caring behavior, which should stem from his/her inner self. Yet usual studies about innovation, should it be in business, economics or sociology, are much more focused on innovation as a process, and thus what innovators do rather than who they $a^{2 e^{56}}$. Even when this issue is tackled, the question of the responsibility of the innovator remains sidelined. Schumpeter saw the innovator as an athlete with a strong taste for conquest, a 'wild spirit' which yearned for success ${ }^{57}$.Recent literature on entrepreneurship questions the personal characteristics of the innovator-entrepreneur, but neither Robert nor Sahlman ${ }^{58}$ deal with the question of responsibility. None of the types of innovators of Alter's typology ('central', 'specialized', 'link' or 'follower') present a characteristic of responsibility ${ }^{59}$. The only aspect stemming from different researches into the profiles of innovators is that innovators are often considered as iconoclasts, eccentrics, exceptions to the norm, drop outs or even deviants "because their behaviors are in opposition with the established social norms" 60 .

\subsection{Stigmatization of Innovation, of Innovators and Self-Control}

One could argue that turning one's behavior into a responsible one means more constraint through increasing control, monitoring and consciously adopting a carefulness not to harm. However there is no point in stigmatizing innovations, or in agreeing with Rousseau who saw progress as the symbol of men's degradation, or in trying to establish that the state of nature would be more profitable ${ }^{61}$.

To understand this view, we must mention two necessary qualities the innovator should have. Firstly, as mentioned earlier, the ability to question the impact of a responsible-innovation, and thus to come to grips with the three aspects Bensaude-Vincent underlined, and secondly, the ability to slow down innovation in an attempt to bring it into line with the economic, social and society's

\footnotetext{
${ }^{53}$ Kant, 2006, p. 97

${ }^{54}$ Kant, 2006, p.108

55 Jonas, 2008

${ }_{56}$ Guichard and Servel, 2006

${ }^{57}$ Schumpeter, 1999; Perroux, 1965

58 Robert, 1991; Sahlman, 1997

59 Alter 2002

${ }^{60}$ Alter, 2003, p.18

${ }^{61}$ Rousseau, 1989
} 
sphere in which it will be implemented. The second of these can easily evolve toward self-control, echoing Stoic techniques. Self-control was closely linked with the notion of freedom ${ }^{62}$ for the Stoics. Being able to control oneself is being free from one's passions, from exterior events and so on. Being able to control oneself for the innovator-carer means to be able to free oneself from the market, from the economic pressure, from situations where an innovation would be launched without having assessed its possible consequences. It also implies that other values and factors, besides the purely economic ones, need to be taken into consideration.

Being able to control oneself for the innovator-carer also means knowing what makes us act and launch this innovation. Why is this innovation good? Is it good by nature, or for me, or for others? That is the control of the innovation process in its deeper consequences. Being able to control oneself also means giving up, just as the Stoic masters showed their ability to give up on their passions. Even if these are attractive and give pleasure, the Stoics endeavored to control their passions so as not to yield to them ${ }^{63}$. They must be able to foresee the actions which could result in pain, because they among others are responsible for everybody's well-being. The entire ethics of care, which relies on the principle of non-violence and of not harming anybody, will thus prevail in the innovation area ${ }^{64}$.

Thus, even if an innovation can significantly increase turnover, contribute to achieving objectives and generate a consistent premium, one should be able to give up on it if it damages the 'care' of the individuals and of the society. The practice of innovator-carer is thus in effect a conscience, not only for the innovator but also for their firms, their organizations and for their society. They act in the common interest, not only in their own. If responsible-innovation involves the assessment of the consequences of an innovation on the community, innovation-care pictures itself as caring for the community. Innovation-care potentially therefore has a positive and benevolent role to play in the community and in civil society, and the innovator-carer is the first student of the ethical Kantian principle "What should I do?" 65 . Responsible-innovation thus is focused on a predetermined role concerning its consequences, while innovation-care takes care of others as a prerequisite.

${ }^{62}$ Schuhl, 1982

${ }^{63}$ Schuhl, 1982

${ }^{64}$ Schuhl, 1982

${ }^{65}$ Kant, 1985, p.25 


\section{CONCLUSION : HOW TO COMBINE CARE AND PERFORMANCE ?}

Kindness and care for others are key-notions concerning innovation-care and contribute to the evolution of the very notion of care. As we said, the meaning of care for its creators is 'to care for the others'. For Janet Finch and Dulcie Groves, care is even a "combination of affectionate feelings and responsibilities" "6. Managers and innovators should become part of the official 'deliverers' of care, as they are in charge of individuals who may become directly or indirectly impacted by their innovations.

We would like to underline the fact that the word care in the expression 'innovation-care' is nevertheless subordinate to the idea of innovation. Although we have claimed that a caringinnovator should know when to give up on innovations, there is no denying that their first attribute is to aim for economic performance in their activity. Last but not least, care is not a frame nor a brake to innovation but rather a process which can be articulated to and with it. It is not the final goal of innovation, since this is measured and evaluated in terms of how far it contributes to performance, growth, sustainability and improvement of the individual's life. To put this point in a different way, innovation must come first, and then care must come first for organizations, leaders, and innovators.

This means that performance is at the core of innovation-care, that there is no possible amphibology in this new generation. Any other interpretation would be a misunderstanding of the meaning of care in general, and of innovation care particularly. Innovation-care does not mean providing a basic service of an inferior quality, pretending that what is important is the 'care for the others'.

Care in itself does not mean just a new form of sympathy. On the contrary, care should be compatible with managerial pragmatism, and should deal with concrete events, with reality. Innovation-care without its focus on innovation would remain a given-without-gift. Tools to evaluate innovation-care can be developed, for example the concept of the Chasm from Moore ${ }^{67}$ or the Matrix Virtue of Martin for instance ${ }^{68}$ - indeed it may be evaluated by existing strategic assessment methods - the Dow Jones Index ${ }^{69}$ - for example.

The Antic philosophy considered that commitment was the necessary condition to implement a philosophic way of life. This commitment was to be found in both the mind and, as well, in actions, it is the very famous articulation of theoria/praxis. It is also the Greek elenchus - the commitment meaning "think well to be able to act well"

In relation to this, innovation-care is only at the very beginning of its existence and its stance remains to be drawn more accurately so that it could be integrated to economic models. Just as the Ancient for the philosophy, innovation-care is to be thought as a commitment. This commitment has two faces: it can be intellectual but it also involves action. Like other sciences, running a business and management must involve integrating these two schemes into innovation-care, for its own development as for that of- individuals and for civil society.

\footnotetext{
${ }^{66}$ Cancias et al, 2000, p.36

${ }^{67}$ Moore, 1999

${ }^{68}$ Martin, 2002

${ }^{69}$ http:/ / www.sustainability-index.com/

${ }^{70}$ Balaudé, 2010, p.188
} 


\section{Bibliography}

Nobert, A.: 2002, 'Entreprise : les innovateurs au quotidien', Futuribles.

Nobert, A.: 2003, L’Innovation ordinaire, (Presse Universitaire de France), p. 18.

Baber, W.: 1983, Organizing The Future: Matrix Models for the Postindustrial Policy, (Alabama, The University of Alabama Press).

Balaudé, J-F.: 2010, Le Savoir vivre philosophique, (Grasset), p. 117, 188

Bostrom, N. and A. Sanders.: 2008, 'The Wisdom of Nature An Evolutionary Heuristic for Human Enhancement', in Human Enhancement, J. Savulescu and Nick Bostrom (eds.), (Oxford University Press), pp. 375-416.

Cancias, F. and O.Stacey.: 2000, Caring and Gender, (Thousand Oaks, Pine Forge Press)

Condorcet, M.J. A.N. C. : 1822, Esquisse d'un tableau historique des progrès de l'esprit humain, (Paris, Masson et Fils), pp. 279-305.

Covin, J.G. and Slevin, D.: 1991, 'A Conceptual Model of Entrepreneurship as Firm Behavior', Entrepreneurship: Theory and Practice, Vol.16 Iss:1, pp. 7-25.

Darwin, C.: 2003, The origin of the species, (Barnes \& noble classics, New York, Fine Creative Media).

Descartes, R.: 1953, Discours de la Méthode, (Gallimard, «Bibliothèque de la Pléiade »), p. 168.

Deschamps, J.P.: 2008, Innovation Leaders, (Jossey-Bass).

Engel, L.: 1997, 'Réguler les comportements', in T. Ferenczi (eds.), De quoi sommes-nous responsables ?, (Éditions Le Monde), pp. 11-36 ; 80-89.

Ewald, F.: 1996, Histoire de l'État-Providence, (Folio), p. 86.

Favaro, K, P-O. Karlsson, and G. L. Neilson.: 2010, 'CEO Succession 2000-2009: A Decade of Convergence and Compression’ Booz\& 20 , Strategy Business, ( ${ }^{\circ} 59$ ).

Fisher, B. and J. Tronto.: 1993, in Joan Tronto, Moral Boundaries. A Political Argument for an Ethic of Care, (New York, Routledge),

Fisher, B. and J.Tronto.: 1990, 'Toward a feminist theory of caring', in E.K. Able, M. Nelson (eds.), Circles of care. Work and Identity in Women's life, (Albany, State University of New York Press).

Franklin, B.: 1956, Mr. Franklin: a selection from his personal letters, (New Haven, Yale University Press), p. 27-29.

Foucault, M.: 2001, 'Le triomphe social du plaisir sexuel : une conversation avec Michel Foucault', in Dits et Ecrits II, 1976-1988, (Gallimard, « Quarto »), p. 1127-1133.

Gagnepain, L.: 2006, 'La climatisation automobile, Impacts consommation et pollution’ in Repères, (published by l'Agence de l'environnement et de la maîtrise de l'énergie - département Technologies des transports).

Gilligan, C.: 2008, Une voie différente. Pour une éthique du care, (Paris, Flammarion), p. 23-25, 50-59, 123.

Guichard, R. and L, Servel.: 2006, 'Qui sont les innovateurs ? Une lecture socio-économique des acteurs de l'innovation', Sociétal, (n52), p. 26-31.

Jonas, H.: 2008, Le principe responsabilité: Une éthique pour la civilisation technologique, (Flammarion), pp. 95-106.

Kant.: 2006, Fondation de la métaphysique des mours in Métaphysique des mours, trad. Alain Renaut, (GF Flammarion), pp. 97 - 108.

Kant.: 1965 Logique, (Vrin), p. 25. 
Knox, S.: 2002, 'The Boardroom Agenda: Developing the Innovative Organisation', Corporate Governance, Vol.2 Iss:1, pp.27-36.

Laugier, S. and P. Paperman.: 2008, 'La voix différente et les éthiques du care’ in C. Gilligan, Une voie différente. Pour une éthique du care, trad. Annick Kwiatek, revue par Vanessa Nurock, (Champ-Flammarion), pp.8-35.

Lumpkin, G.T. and Dess, G.G.: 1996, 'Clarifying the Entrepreneurial Orientation Construct and Linking it to Performance', Academy of Management Review, Vol.21, pp.135-172.

Neuberg, M.: 1997, La Responsabilité : questions philosophiques. (Presses universitaires de France).

Molinier. P, S. Laugier and P. Paperman.: 2009, Qu'est-ce que le care? (Petite Bibliothèque Payot), pp.7-19.

Moore, G. A.: 1999, Crossing the Chasm, Marketing and Selling High-Tech Products to Mainstream Customer, (HarperCollins Publishers, New York).

Martin, R.: 2002, 'Virtue Matrix: Calculating the Return on Corporate Responsibility', Harvard Business Review (HBR OnPoint Enhanced Edition).

Ost, F.: 1995, La Nature hors la loi, (La Découverte), p. 267.

Platon.: 1950, République, trad. Léon Robin, in Platon, EEurres complètes I, (Gallimard, Bibliothèque de la Pléiade), IV, 420b, p. 980.

Perroux, F.: 1965, La Pensée économique de Joseph Schumpeter, (Presse de Savoie), p. 83.

Porter. M and M. Kramer.: 2011, 'Shared Value. How to reinvent capitalism -and unleash a wave of innovation and growth', Harvard Business Review.

Rabelais, F.: 1854, Pantagruel in CEuvres, (Paris, J. Bry Ainé), p. 107.

Raymond, J.: 2003, 'La Ford Pinto : le contre-exemple américain', Le Polyscope, (Le journal de l'École polytechnique de Montréal), vol. 36.

Ricœur Paul, 1995, 'Le concept de responsabilité. Essai d'analyse sémantique', in Le Juste 1, (Paris, Seuil), p. $41-70$.

Rousseau.: 1989, Discours sur l'origine et les fondements de l'inégalité parmi les hommes, (Flammarion), pp. 215-250

Robert, E.B.: 1991 Entrepreneuship in High Technology: Lessons from MIT Beyond, (New York, OUP).

Sahlman, W.A.: 1997, 'How to write a great business plan’, Harvard Business Review, (n 75, vol. 4).

Shaw, W. H. \& Barry, V. (1995). Moral Issues in Business, 6th Edition, Belmont, Wadsworth Publishing Company.

Shusterman, R. : 2001, Vivre la philosophie - Pragmatisme et art de vivre, trad. Christian Fournier et Jean-Pierre Cometti, (KlincKsieck), p. 45.

Schumpeter, J.: 1939, Business Cycles: A Theoretical, Historical, and Statistical Analysis of the Capitalist Process, (New York McGraw-Hill), p. 105.

Schumpeter J.: 1999, Théorie de l'évolution économique, trad. Jean-Jacques Askett, (Dalloz).

Sophocle.: 1955, Antigone, trad. P. Mazon, (Les Belles Lettres), p. 86.

Schwartz, M.: 2005, 'Universal Moral Values for Corporate Codes of Ethics', Journal of Business Ethics, (n 59), pp. 27-44. 
Schuhl, P-M and E. Bréhier. : 1962, 'Introduction' in Les Stoïciens, textes traduits par É. Bréhier, (Gallimard, Bibliothèque de la Pléiade).

Tronto, J.: 2009, 'Care démocratique et démocraties du care', trad. B. Ambroise, in P. Molinier, S. Laugier and P. Paperman, Qu'est-ce que le care? (Petite Bibliothèque Payot), pp. 36-54.

Tronto J.: 2009, Moral Boundaries: A Political Argument for an Ethic of Care, (Routledge), trad. française, Un monde vulnérable. Pour une éthique du care, (La Découverte), p. 143.

Williams, B.: 1990, L'Éthique et les Limites de la philosophie, trad. A.-M. Lescourret, (Gallimard), p. 7. 
ESSEC Business School Avenue Bernard Hirsch BP 50105

95021 Cergy-Pontoise Cedex

France

Tél. +33(0)134433000

$\mathrm{Fax}+33(0) 134433001$

www.essec.fr

\section{ESSEC Executive Education} CNIT BP 230

92053 Paris-La Défense France

Têl. +33(0)146924900

Fax +33(0)1 46924990

http://formation.essec.fr

ESSEC Business School

Singapore Campus

100 Victoria Street

National Library Building \# 13-02

Singapore 188064

essecasia@essec.fr

Tél. +6568849780

Fax +6568849781

www.essec.edu

Informations

Alison Bougi

+33 (0)134433358

bougi@essec.fr

www.essec.fr

research.center@essec.fr

ISSN 1291-9616 